\title{
Evaluasi Knee Ankle Foot Ortosis Dengan Parameter Spatiotemporal Dan Keseimbangan Pada Pengguna dengan Polio
}

\author{
Fika Trifani ${ }^{1}$, R.Achmad Candra Putra ${ }^{2}$, Tri Riana Lestari ${ }^{3}$ \\ 1,2,3Prodi DIV Ortotik Prostetik Politeknik Kesehatan Kementerian Kesehatan Jakarta I \\ Jakarta, Indonesia \\ Email: fika@poltekkesjakarta1.ac.id
}

\begin{abstract}
Abstrak
Alat bantu knee-ankle-foot orthosis (KAFO) umum di preskripsikan bagi pasien dengan riwayat poliomyelitis dan berfungsi untuk memperbaiki gaya berjalan dan mencegah degenerasi sendi lutut. Namun, saat ini efek penggunaan knee ankle foot orthosis pada pasien monoplegia polio saat berjalan belum pernah di evaluasi. Tujuan penelitian ini adalah untuk menganalisa adaptasi biomekanik terutama pada parameter spatiotemporal dan stabilitas saat subjek berjalan dengan dan tanpa alat bantu KAFO. Metode : Lima belas subjek monoplegia dengan poliomyelitis diuji dengan dua analisa gaya berjalan (yaitu dengan dan tanpa alat bantu KAFO). Parameter spatiotemporal di uji dengan menggunakan instrument 10 Meter Walk Test (10MWT), sedangkan stabilitas saat berjalan di uji dengan instrument uji Timed up and Go (TUG). Data dari parameter spatiotemporal yang didapat di analisa dengan menggunakan uji $\mathrm{T}$ berpasangan., dan uji McNemar digunakan untuk menganalisa variabel stabilitas saat berjalan. Kedua analisa tersebut akan menganalisa perbedaan parameter yang diuji saat subjek berdalan dengan dan tanpa alat bantu KAFO. Signifikan level yang digunakan adalah $p<0.05$. Hasil : Hasil penelitian menunjukkan terdapat perbedaan signifikan pada parameter spatiotemporal dan stabilitas saat subjek berjalan dengan dan tanpa alat bantu KAFO. Alat bantu ini meningkatkan parameter spatiotemporal dan stabilitas saat subjek berjalan menggunakan KAFO dibandingkan dengan saat mereka tidak menggunakan ortosis sama sekali. Saat fase stance di kaki yang mengalami paralisis, hiperekstensi pada lutut dan fleksi berlebih pada lutut berkurang, sedangkan fleksi pada sendi pinggul meningkat. Stabilitas berjalan meningkat pada $60 \%$ subjek saat mereka menggunakan KAFO ketika berjalan. Penelitian ini menemukan bahwa kompensasi gaya berjalan juga berkurang saat subjek berjalan menggunakan KAFO, dan melalui umpan balik langsung subjek menyatakan bahwa berjalan meenggunakan KAFO membuat mereka tidak mudah lelah dan dapat berjalan lebih jauh.
\end{abstract}

Kata kunci : Knee Ankle Foot Orthosis, Poliomyelitis, Monoplegic, Stabilitas

The knee-ankle-foot orthosis (KAFO) tool is commonly described for patients with a history of poliomyelitis and serves to improve gait and prevent degeneration of the knee joint. However, at present the effect of using knee ankle foot orthosis in monoplegia polio patients when walking has never been evaluated. The purpose of this study was to analyze biomechanical adaptation especially in spatiotemporal parameters and stability when the subjects walked with and without KAFO aids. Methods: Fifteen monoplegia subjects with poliomyelitis were tested with two gait analyzes (i.e. with and without KAFO aids). Spatiotemporal parameters were tested using the 10 Meter Walk Test (10MWT) instrument, while stability when running was tested with the Timed up and Go (TUG) test instrument. Data from the spatiotemporal parameters obtained were analyzed using paired $\mathrm{T}$ tests, and the McNemar test was used to analyze the stability variables while walking. Both analyzes will analyze differences in parameters tested when subjects are in line with and without KAFO tools. Significant level used is $p<0.05$. Results: The results showed that there were significant differences in spatiotemporal parameters and stability when subjects walked with and without KAFO aids. This tool increases spatiotemporal parameters and stability when the subject runs using KAFO compared to when they did not use orthosis at all. When the stance phase in the leg is paralysis, hyperextension in the knee and excessive flexion of the knee is reduced, while flexion in the hip joint increases. Walking stability increased in $60 \%$ of subjects when they used KAFO when walking. This study found that gait compensation was also reduced when subjects walked using $\mathrm{KAFO}$, and through direct feedback the subject stated that walking using KAFO made them not easily tired and could go further.

Key words : Knee Ankle Foot Orthosis, Poliomyelitis, Monoplegic, Stability 


\section{Pendahuluan}

Polio atau poliomyelitis merupakan penyakit menular akut yang disebabkan oleh virus yang menyerang sel anterior sumsum tulang belakang dan inti motorik batang otak yang mengakibatkan terjadinya kelumpuhan dan atrofi pada otot.

Penatalaksanaan manajemen Ortotik bagi pasien Polio sangat kompleks. Beberapa masalah biomekanik pada pasien polio antara lain : inadekuat dorsi fleksi pada engkel saat fase swing, dorsi fleksi kolaps pada fase stance, genu recurvatum (lutut melengkung ke belakang), genu valgum (lutut menyerupai bentuk "X"), dan instabilitas pada ligamen medio-lateral pada sendi engkel. Berdasarkan beberapa masalah tersebut, desain ortosis akan berbeda tergantung kebutuhan pasien.

Menurut Gene ${ }^{1}$, ortosis memiliki peran penting dalam rehabilitasi pasien polio. Tujuan utama alat ini umumnya untuk menjaga lutut pada posisi normal, mencegah terjadinya recurvatum berlebihan pada saat pasien berdiri dan berjalan.

Salah satu tipe ortosis ekstrimitas bawah yang umum di preskripsikan bagi pasien yang mengalami kelumpuhan seperti polio adalah Knee Ankle Foot Ortosis (KAFO). Alat bantu KAFO memberikan stabilitas saat berjalan dengan mekanisme penguncian lutut dalam posisi ekstensi penuh saat fase stance dan swing. Namun disisi lain, berjalan menggunakan alat bantu KAFO juga dapat membuat lebih cepat lelah saat ambulasi, membatasi pergerakan, sakit, dan mengurangi lingkup gerak sendi (LGS) pada persendian ekstrimitas bawah ${ }^{2,3}$.

Dalam hasil studi pro dan kontra tersebut, efek pada parameter berjalan saat menggunakan alat bantu ortosis di Indonesia belum cukup jelas. Penelitian ini ingin melakukan evaluasi terhadap perbedaan hasil yang diberikan oleh alat bantu KAFO pada pasien polio berdasarkan parameter spatiotemporal dan keseimbangan pasien saat menggunakan dan tidak menggunakan KAFO.

Berdasarkan latar belakang tersebut, penelitian ini ingin menunjukkan adanya perbedaan kemampuan berjalan pada klien dengan polio dilihat dari parameter spatiotemporal dan keseimbangan saat pasien menggunakan alat bantu KAFO dan saat tidak menggunakan alat bantu.

\section{Metode}

Protokol penelitian telah direview dan di setujui oleh tim kaji Etik Poltekkes Kemenkes Jakarta I, Jakarta-Indonesia (86/KEPK/IX/2017). Data pemeriksaan obyektif dan subyektif telah mengikuti formulir pengambilan data. Seluruh responden yang digunakan dalam penelitian ini, menggunakan alat bantu Knee Ankle Foot Orthosis (KAFO) yang dibuat oleh Prodi DIV Ortotik Prostetik Poltekkes Kemenkes Jakarta I.

Lima belas (15) orang dengan polio dan kelayuan pada salah satu sisi kaki (monoplegia) namun dapat berambulasi secara aktif di komunitas menjadi responden dalam penelitian ini. Mean umur adalah 41.4 tahun ( $\mathrm{SD}=5.6)$, dengan mean lama penggunaan KAFO adalah 3.2 tahun $(\mathrm{SD}=1.2)$.

Uji stabilitas dan spatio-temporal dilaksanakan di Laboratorium Klinik Prodi DIV Ortotik Prostetik Jakarta I.. Setiap subyek diminta untuk melakukan satu sesi analisa gaya berjalan (gait analysis) dengan uji 10MWT dengan dan tanpa menggunakan KAFO, parameter yang diujikan adalah kecepatan berjalan dan cadence. Setelah itu, subjek melanjutkan Uji Timed Up and Go (TUG) untuk menginvestigasi keseimbangan saat subyek menggunakan dan tidak menggunakan KAFO.

\section{Hasil}

Gambaran parameter spatio-temporal (kecepatan berjalan dan cadence pada subyek polio dengan dan tanpa menggunakan alat bantu KAFO dapat dilihat pada tabel 1.

Gambaran keseimbangan dan resiko jatuh pada subyek polio dengan dan tanpa menggunakan alat bantu KAFO dapat dilihat pada tabel 2.

TABLE I. DISTRIBUSI KECEPATAN BERJALAN (SPEED), CADENCE, DAN KESEIMBANGAN PADA 
PASIEN POLIO TANPA DAN DENGAN MENGGUNAKAN ALAT BANTU KAFO (M/S)

\begin{tabular}{lllll}
\hline Variabel & $\begin{array}{l}\text { Mean } \\
\text { Median }\end{array}$ & SD & $\begin{array}{l}\text { Min } \\
\text { Maks }\end{array}$ & $\begin{array}{l}\text { 95\% } \\
\text { CI }\end{array}$ \\
\hline $\begin{array}{l}\text { Kecepatan } \\
\text { tanpa }\end{array}$ & 0.53 & 0.20 & 0.33 & $0.42-$ \\
KAFO & 0.45 & & 0.85 & 0.65 \\
Kecepatan & & & & \\
dengan & 0.73 & 0.14 & 0.52 & $0.65-$ \\
KAFO & 0.76 & & 0.97 & 0.81 \\
Cadence & 74.13 & 13.5 & 60.00 & $66.62-$ \\
tanpa & 66.00 & 7 & 90.00 & 81.65 \\
KAFO & & & & \\
Cadence & 86.80 & 6.22 & 78.00 & $83.35-$ \\
KAFO & 86.00 & & 96.00 & 90.25 \\
\hline
\end{tabular}

TABLE II. DISTRIBUSI MENURUT KESEIMBANGAN PADA PASIEN POLIO TANPA DAN DENGAN MENGGUNAKAN ALAT BANTU KAFO

\begin{tabular}{lll}
\hline $\begin{array}{l}\text { Variabel } \\
\text { Keseimbangan } \\
\text { tanpa KAFO }\end{array}$ & Jumlah & Persentase \\
$\begin{array}{l}\text { a. Mobilitas } \\
\quad \text { Baik }\end{array}$ & 3 & 20 \\
b. $\begin{array}{l}\text { Resiko } \\
\quad \text { Jatuh }\end{array}$ & 12 & 80 \\
$\begin{array}{l}\text { Keseimbangan- } \\
\text { KAFO }\end{array}$ & 9 & 60 \\
$\begin{array}{l}\text { Mobilitas } \\
\text { a. }\end{array}$ & 6 & 40 \\
b. Resiko Jatuh & & \\
$\quad$ Jumlah & 15 & 100 \\
\hline
\end{tabular}

\section{Pembahasan}

Tujuan utama penelitian ini adalah untuk melakukan evaluasi terhadap performa berjalan dan keseimbangan pada pasien polio paralisis dengan dan tanpa menggunakan Knee
Ankle Foot orthotis (KAFO). Selama observasi, terdapat perbedaan yang jelas pada gaya berjalan subjek saat menggunakan dan tidak menggunakan KAFO. Perbedaan ini terlihat saat subjek berjalan pada fase stance di poin midstance. Saat tidak menggunakan KAFO, terlihat subjek menggunakan tangannya untuk mendorong paha ke belakang pada kaki yang paralisis (gambar 1). Gaya berjalan ini dikenal dengan hand trust yang disebabkan oleh lemahya otot quadriceps (otot ekstensor sendi lutut). Lemahnya otot ekstensor lutut menurut Perry ${ }^{4}$, merupakan salah satu yang umum dilihat pada pasien polio. Kelemahan otot-otot ini dapat menyebabkan lutut menjadi hiperekstensi dan terjadinya fleksi lutut yang inadekuat, terutama saat fase loading (poin heel strike ke midstance). Masalah ini dapat diminimalisir dengan penggunaan KAFO.

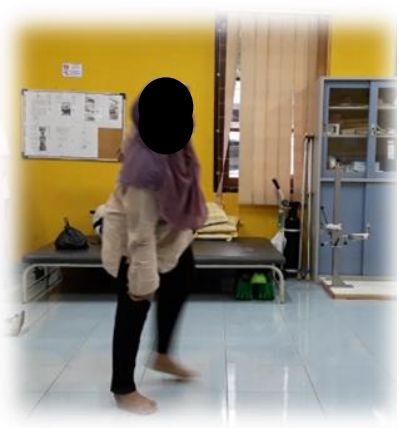

Tidak menggunakan KAFO (hand trust)

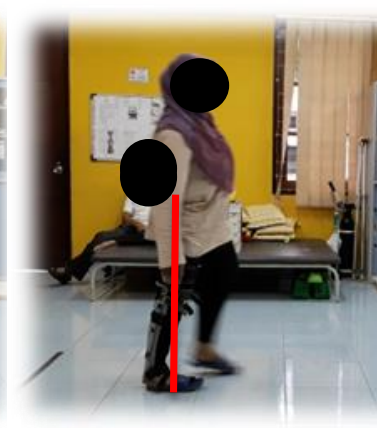

Berjalan dengan menggunakan KAFO
Gambar 1. Gaya berjalan saat fase stance (poin mid stance) tanpa dan dengan menggunakan alat bantu KAFO. Garis merah menunjukkan Ground Reaction Force (GRF).

Hasil observasi pada gaya berjalan sejalan dengan hasil penelitian Hurmuzlu ${ }^{5}$ yang menyatakan bahwa lutut pada pasien polio saat fase load acceptance menjadi hiperekstensi dibandingkan dengan pasien non-polio. Salah satu penyebab hal ini adalah berkurangnya kecepatan saat heel strike pada pasien polio yang diamati. Selain itu penyebab lain yang bekaitan dengan terjadinya ekstensi lutut berlebih ini 
berkaitan dengan meningkatkan plantar fleksi engkel (lemahnya otot dorsi fleksor) serta kecenderungan pergerakan fleksi sendi pinggul secara berlebih.

\section{Keseimbangan}

Hasil penelitian ini menunjukkan sebanyak $80 \%$ subjek penelitian memiliki resiko jatuh saat berjalan tanpa menggunakan alat bantu KAFO. Hal ini sesuai dengan penelitian Hurmuzlu ${ }^{4}$ yang menemukan bahwa pasien polio berjalan secara signifikan kurang stabil dibandingkan orang yang normal. Penyebab utama hilangnya stabilitas dinamik ini dikarenakan lemahnya otot plantar fleksor.

Berkaitan dengan pernyataan Hurmuzlu tersebut, tercatat bahwa keseluruhan subjek penelitian ini memiliki masalah terkait lemahnya otot plantar fleksor dan otot dorsi fleksor. Hal tersebut menyebabkan penambahan resiko instabilitas bahkan resiko jatuh pada subjek saat berjalan.

\section{Analisa Spatiotemporal}

Penelitian ini menunjukan bahwa terdapat perbedaan yang signifikan pada parameter kecepatan berjalan dan cadence saat subjek berjalan tanpa dan dengan alat bantu KAFO. Kecepatan berjalan dengan menggunakan KAFO tercatat lebih lama dibandingkan saat subjek berjalan tanpa menggunakan alat bantu KAFO. Hal ini juga menyebabkan gaya berjalan asimetri pada parameter spatio temporal. Terminology "gaya berjalan asimetri" didefinisikan sebagai gaya berjalan dengan tidak ditemukannya perbedaan yang signifikan antara kedua kaki ${ }^{6}$.

Menurut Portnoy ${ }^{7}$ karakteristik gaya berjalan subjek poliomyelitis adalah melambatnya kecepatan berjalan dan cadence, panjangnya durasi face stance, dan lebih pendeknya panjang langkah pada kaki yang paralisis. Pernyataan tersebut sejalan dengan hasil penelitian ini yaitu lebih lambatnya kecepatan berjalan dan cadence saat subjek berjalan dengan menggunakan KAFO.
Penelitian ini juga menunjukkan bahwa KAFO meningkatkan parameter spatiotemporal. Saat fase stance pada sisi kaki yang paralisis, terdapat pengurangan hiperekstensi lutut (genu recurvatum), sedangkan gerakan fleksi pada pinggul meningkat. Momen fleksi lutut pada sisi kaki yang paralisis juga menurun. Adaptasi parameter spatiotemporal ini diduga berkaitan erat dengan menurunnya hiperekstensi lutut saat stance dan meningkatnya dorsifleksi pergelangan kaki di kedua fase berjalan (stance dan swing) yang sejalan dengan penelitian Boudarham $^{8}$.

\section{Limitasi Penelitian}

Kecilnya sampel penelitian menjadi limitasi utama dalam penelitian ini, yang menyebabkan berkurangnya kemampuan untuk menggeneralisir hasil penelitian ini. Jumlah subjek penelitian belum berimbang antara lakilaki dan perempuan, hal ini menjadikan hasil penelitian belum cukup mampu menggambarkan hasil bagi kedua gender.

\section{Temuan lapangan}

Selain data spatiotemporal dan keseimbangan, deviasi gaya berjalan merupakan hal yang sangat mudah diamati dari subjek dengan polio. Setiap subjek walaupun memiliki masalah utama yang sama, namun menunjukkan gaya kompensasi berjalan yang berbeda pada saat berjalan dengan dan tanpa alat bantu KAFO. Saat subjek berjalan dengan KAFO, teramati perubahan postur berdiri maupun berjalan. Hal ini dapat dijadikan topik penelitian selanjutnya untuk meneliti perbedaan deviasi gaya berjalan dan bagaimana pasien polio beradaptasi dan melakukan gaya kompensasi berjalan dengan alat bantu KAFO.

\section{Kesimpulan dan Saran}




\section{Penelitian ini menunjukkan bahwa alat bantu Knee Ankle Foot Orthosis (KAFO) meningkatkan parameter spatiotemporal dan stabilitas ketika berjalan. Terdapat perbedaan yang signifikan pada kecepatan berjalan dan cadence saat subjek berjalan dengan dan tanpa alat bantu KAFO.}

[16] Rampengan, T.H. 2008. Penyakit Infeksin Tropik pada Anak Edisi Kedua. Jakarta: EGC

\section{Daftar Pustaka}

[1] Gene F, et al. 2010. "Orthotic devices and gait in polio patient". Ann Phys Rehabil Med. 2010 Feb;53(1):51-9

[2] Zissimopoulos, A, Fatone, S, Gard, S.A. 2007. "Biomechanical and energetic effects of a stance-control orthotic knee joint", in Journal of Rehabilitation Research \& Development Vol 44, Number 4, 2007, Pp 503-514

[3] Mcmillan, T, Baliga, S, Sutherland, A and Sharan D. 2015. "The prevalence and severity of joint problems and disability in patients with poliomyelitis in urban India", in Open Orthop J. 2015; 9: 204-209. Published online 2015 Jun 26.

[4] Perry, J. 1992. Gait Analysis: Normal and Pathological Function. Slack Incorporated.

[5] Hurmuzlu, Y, Basdogan C, Stoianovici D. 1996. "Kinematics and dynamic stability of the locomotion of postpolio patients", in J Biomech Eng. 1996 Aug;118(3):405-11.

[6] Arazpour, M, et. al. 2016. "Evaluation of Gait Symmetry in Poliomyelitis Subjects : Comparison Of Conventional Knee Ankle Foot Orthosis (KAFO) and a New Powered KAFO" http://usir.salford.ac.uk/35402

[7] Portnoy, S. 2013. Gait Characteristics of Post-Poliomyelitis Patients : Standardization Of Quantitive Data Reporting. Annals of Physical and Rehabilitation Medicine. Vol 56, Issues 7-8, October 2013, pages 527-541.

[8] Boudarham, J, R. Zory, F. Genet, G. Vigné, D. Bensmail, N. Roche, D. Pradon. 2013. "Effects of a knee-ankle-foot orthosis on gait biomechanical characteristics of paretic and non-paretic limbs in hemiplegic patients with genu recurvatum", in Clinical Biomech 2013, Vol 28, Issue 1, Pp 73-78.

[9] UNICEF Indonesia. 2011. Child Health and Nutritions. https://www.unicef.org/indonesia/health_nutrition_3031.ht $\mathrm{ml}$

[10] UNICEF Indonesia. 2012. Child Health and Nutritions. https://www.unicef.org/indonesia/health_nutrition_3136.ht $\mathrm{ml}$

[11] Widoyono. 2011. Penyakit Tropis Epidemiogi, Penularan, Pencegahan \& Pemberantasannya Edisi kedua. Jakarta: Erlangga.

[12] World Health Organization. 2009. Management of Poliomyelitis. Ministry of health and Social Protection of the Population Republic of Tajikistan.

[13] Jacobs M, Fox T. 2008. Using the "Timed Up and Go/ TUG" test to predict risk of falls. Assisted Living Consult; 2:16-18

[14] Skough K. 2013. Post Polio Syndrome-Physiotherapeutic Analysis and intervensions. https://openarchive.ki.se/xmlui/bitstream/handle/10616/413 39/Thesis Katarina Skough.pdf?sequence=2

[15] Profil Kesehatan Indonesia. 2015. Kementerian Kesehatan Republik Indonesia. 